Swarthmore College

Works

Spring 2018

\title{
Sociolinguistics II: Deviance, Dystopia, And Democracy (LING82) Syllabus
}

Jamie A. Thomas

Swarthmore College, jthomas6@swarthmore.edu

Follow this and additional works at: https://works.swarthmore.edu/dev-dhgrants

Part of the Linguistics Commons

\section{Recommended Citation}

Jamie A. Thomas. (2018). "Sociolinguistics II: Deviance, Dystopia, And Democracy (LING82) Syllabus". Sociolinguistics II: Deviance, Dystopia, And Democracy. DOI: 10.24968/2476-2458.dhgrants. 15

https://works.swarthmore.edu/dev-dhgrants/15

\section{(c) (i)}

This work is licensed under a Creative Commons Attribution 4.0 License.

This work is brought to you for free by Swarthmore College Libraries' Works. It has been accepted for inclusion in Digital Humanities Curricular Development by an authorized administrator of Works. For more information, please contactmyworks@swarthmore.edu. 


\section{Sociolinguistics II: \\ Deviance, Dystopia, and Democracy (LING82)}

Professor Jamie Thomas

jthomas6@swarthmore.edu; @jamieisjames

Monday 1:15-4pm, Pearson Hall 115

Spring 2018

"...When enough people make false promises, words stop meaning anything.

Then there are no more answers, only better and better lies. And lies won't help us in this fight." - John Snow, Game of Thrones (2017)

"We are taking language not as a system of abstract grammatical categories, but rather language conceived as ideologically saturated, language as a world view..."

- Mikhail Bakhtin (1982)

\section{Course description}

This course builds upon foundational concepts in sociolinguistic theory to examine discourses of news and entertainment media, across science fiction and politics. Drawing upon contributions in applied linguistics, media studies, cultural studies, and archival research, we ask which realities are mirrored in our everyday language and in the fictional and sensationalized worlds we engage in through the media we consume. What role does science fiction play in our explorations of social difference, deviance, control, disability, sexuality, and normativity? Can science fiction assist the goals of social justice and democracy? How does language surface in the biopolitics of human and non-humans? Together, we will explore key film and television, and select novels by authors Max Brooks, Octavia Butler, and Philip K. Dick. Students will learn advanced methods and theories in multimodal critical discourse analysis and digital humanities.

\section{Course goals}

1. Approach words and images as tools in communication, social construction, and domination.

2. Appreciate how social networks and group ideologies drive our interpretation of others.

3. Identify how privileged access to social resources (linguistic varieties, education, knowledge, and wealth) is reified or challenged through the everyday language and presentation of news and entertainment.

4. Examine works of radical imagining to challenge our existing concepts of 'power' and 'justice'.

\section{Required readings and materials}

Any additional assigned readings and materials will be posted on Moodle. As you read and reflect, you should use the discussion forum feature on Moodle to engage your peers with questions of your own making.

Key textbook:

- Machin, David, \& Mayr, Andrea. (2012). How to do critical discourse analysis: A multimodal introduction.

(Non)fiction works centering zombies, vampires, and other human(oid) bodies:

- Brooks, Max. (2006). World War Z: An oral history of zombie war. New York: Three Rivers Press.

- Butler, Octavia E. (2005). Fledgling. New York: Grand Central Publishing.

- Dick, Philip K. (1962 [2011]). The man in the high castle. New York: First Mariner Books.

- Northup, Solomon. (1853 [1970]). Twelve years a slave. Mineola, NY: Dover Publications.

\section{Key assignments}

- Weekly: Bring readings to class \& artifact of news reporting or entertainment for us to discuss

- 3 Short essays: 700-word analytical responses to news/entertainment

- We will collaborate together as a seminar to publish your $3^{\text {rd }}$ short essay online as part of the [ZOMBIES REIMAGINED] digital humanities project.

- Final project: Write your own fictional dystopic story that addresses \& critiques a real-life problem 
Office hours (Mondays, 4-5:30p or by appointment, Pearson 107)

Drop by and say hi!

\section{Course grade}

Seminar attendance and participation $\quad 25 \%$

- leading discussion in class

In-class and other assignments $\quad 30 \%$

Midterm exam $15 \%$

Final project $30 \%$

${ }^{* *}$ Students who attend linguistics and/or literary events (talks, presentations) and do a 1-pg write-up can obtain extra credit.

\section{For students with disabilities}

If you believe that you need accommodations for a disability, please contact the Office of Student Disability Services (Parrish 113W) or email studentdisabilityservices@swarthmore.edu to arrange an appointment to discuss your needs. As appropriate, the Office will issue students with documented disabilities a formal Accommodations Letter. Since accommodations require early planning and are not retroactive, please contact the Office of Student Disability Services as soon as possible. For details about the accommodations process, visit the Student Disability Service Website at http://www.swarthmore.edu/academic-advising-support/welcome-to-student-disability-service. You are also welcome to contact me-Prof. Thomas_privately to discuss your academic needs. However, all disabilityrelated accommodations must be arranged through the Office of Student Disability Services.

\section{Tentative Course Outline - Deviance, Dystopia, Democracy (LING82) - Prof. Thomas}

${ }^{* *}$ Students lead discussion on select days - updated schedule posted to Moodle

Among the topics we may explore:
- dialects
- resistance movements
- fake news
- Israeli occupation
- enslavement
- racialization
- disabilities
- gender(s)

\begin{tabular}{|c|c|}
\hline $\begin{array}{r}\text { Week } \\
1\end{array}$ & $\begin{array}{l}\text { Monday, Jan. } 22 \\
\text { What about culture is intrinsic to language? } \\
\text { How does study of language use and communication connect to studies of popular culture? }\end{array}$ \\
\hline $\begin{array}{r}\text { Week } \\
2\end{array}$ & $\begin{array}{l}\text { Jan. } 29 \\
\text { - The Man in the High Castle (Ch. 1-8) } \\
\text { - Intro + Ch. } 1 \text { of How to do CDA (Language as a set of resources) }\end{array}$ \\
\hline $\begin{array}{r}\text { Week } \\
3\end{array}$ & $\begin{array}{l}\text { Feb. } 5 \text { - Semiotics and Speculative Violence } \\
\text { - The Man in the High Castle, Ch. 9-12 } \\
\text { - Bakhtin on "Discourse and the novel" } \\
\text { - Chapter from Conquest by Andrea Abrams } \\
\text { - (optional) Dell Hymes on the SPEAKING mnemonic } \\
\text { **Fieldtrip: Black Lives Matter community discussion and Precious Knowledge documentary } \\
\text { screening event (LaSalle Univ.) } \\
\text { Homework for Week 4: } \\
\text { - Essay 1: } 600 \text {-word essay that takes up the standpoint of a "politics of } \\
\text { intersectionality" to describe what 1-2 elements of Philip K. Dick's novel you find } \\
\quad \text { most meaningful in illuminating our current (actual) societal situation. } \\
\text { To do this, you should also identify 1-2 social problems IRL as suggested by Dick's } \\
\text { novel, or your own observations/experiences. }\end{array}$ \\
\hline
\end{tabular}




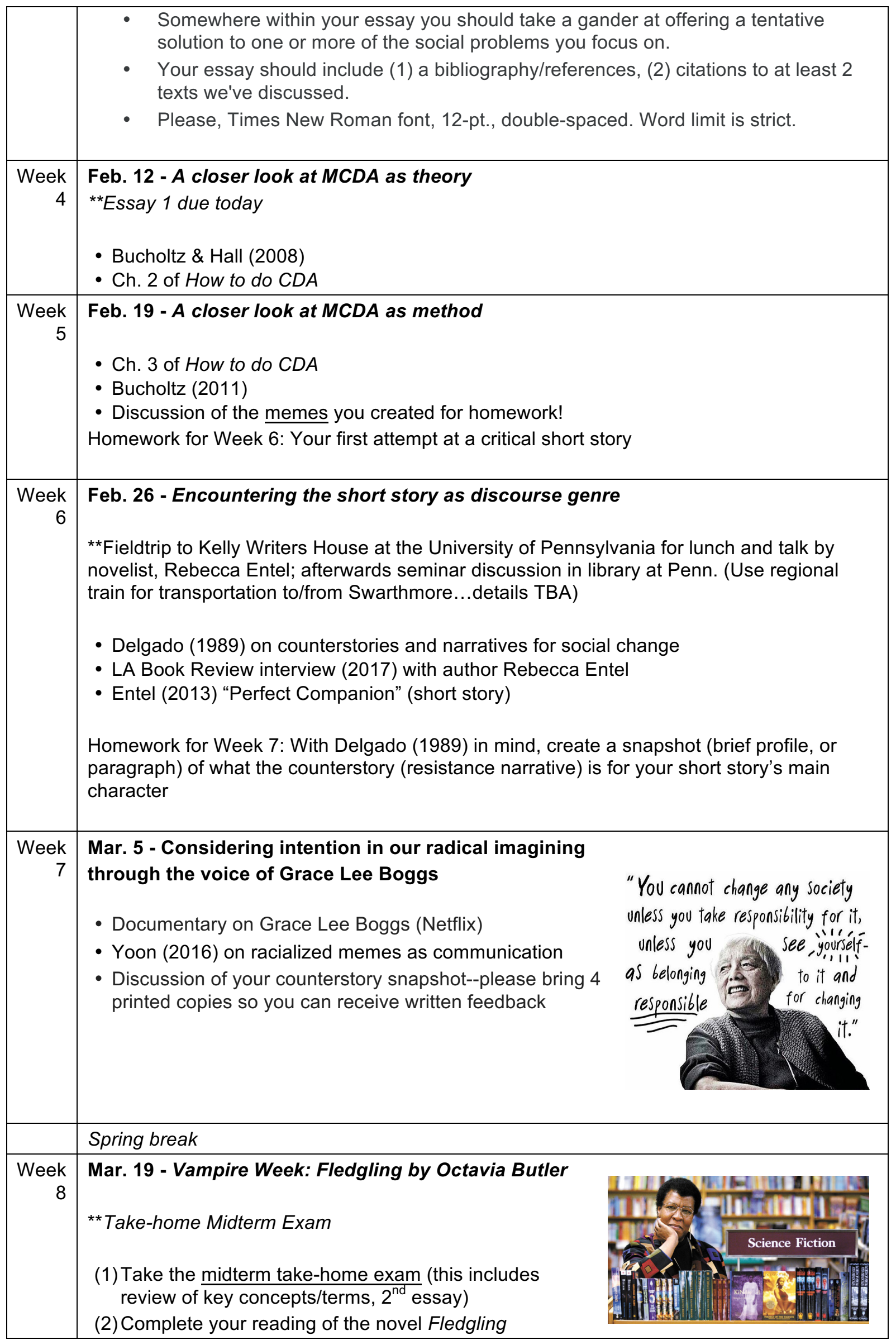




\begin{tabular}{|c|c|}
\hline & $\begin{array}{l}\text { peers on their short stories } \\
\text { our feedback. }\end{array}$ \\
\hline & $\begin{array}{l}\text { Mar. } 26 \text { - Discourses of Vampires and Antislavery } \\
\text { dise'll meet first in our usual meeting place, Pearson 115, to } \\
\text { discuss your responses to the novel Fledgling (Essay 2). } \\
\text { **Fieldtrip: For the final } 2 \text { hours of class, we'll move to } \\
\text { the Friends Historical Library (McCabe Library on campus). At } \\
\text { the library, we'll meet with archivist Celia Caust-Ellenbogen for } \\
\text { a workshop in examining antislavery discourses from the } \\
\text { Antebellum period of the U.S. } \\
\text { - This workshop will serve as a way of introducing us to } \\
\text { discourses from the historical period in which our next major } \\
\text { reading is set: Twe/ve Years a Slave. } \\
\text { - This opportunity should also give us firsthand experience } \\
\text { working with primary source material/data that, like our examination of Thomas } \\
\text { Jefferson's Notes on the State of Virginia (1781-83), pertain to discourses foundational to } \\
\text { contemporary American democracy. } \\
\text { In preparation for our visit to the archives, please prepare the following readings: } \\
\text { - From our textbook on CDA, Ch. 4, "Representing people: Language and identity" } \\
\text { - Caust-Ellenbogen on "White Slaves" } \\
\text { - A look (and listen) at two speeches by former enslaved person and abolitionist activist, } \\
\text { Sojourner Truth } \\
\text { - As hou read/listen, consider what key concepts in MCDA you can use to examine the } \\
\text { semiotic choices of speakers/authors and others. In what ways do their semiotic choices } \\
\text { reflect their differing concepts of 'power' and 'justice'? }\end{array}$ \\
\hline $\begin{array}{r}\text { Week } \\
10\end{array}$ & $\begin{array}{l}\text { April } 2 \text { - More Antebellum Discourses (Twelve Years a Slave, Ch. 1-12) } \\
\text { **Student presentations \& handouts } \\
\text { - REVIEW your contemporary cultural artifacts of significance (e.g., form news or } \\
\text { entertainment); Remember to frame your informal presentation by explaining how your } \\
\text { data illustrate a key analytical concept in MCDA (e.g., representation, agency, salience) } \\
\text { - DISCUSS \& REFLECT on our experience in the Quaker archives, and what we've } \\
\text { learned about the sociohistorical context of discourse and communication. } \\
\text { - EXAMINE notions of 'power' and 'justice' within the first half of the narrative, Twelve } \\
\text { Years a Slave. In order to do this, each student will read Ch. } 5 \text { from our CDA textbook } \\
\text { (Representing Action) AND present on select chapters from TYaS, by preparing } \\
\text { a HANDOUT that includes: } \\
\text { (1) A brief summary of the general events transpiring in the selected chapters } \\
\text { (2) 1-2 excerpts each from the book/narrative (as sources of data) that correspond to/or } \\
\text { demonstrate aspects of any } 3 \text { of the following key concepts: } \\
\text { 1. over- /underlexicalization } \\
2 \text {. habitus }\end{array}$ \\
\hline
\end{tabular}




\begin{tabular}{|c|c|}
\hline & $\begin{array}{l}\text { 3. salience } \\
\text { 4. representation } \\
\text { 5. agency } \\
\text { 6. connotation } \\
\text { 7. structural oppositions } \\
\text { 8. suppression } \\
\text { 9. language ideology } \\
\text { (3) 1-2 questions for discussion, that help us explore why/how Northrup's story } \\
\text { challenges our imagining of 'power' and 'justice', or helpful in the exploration of } \\
\text { MCDA as part of sociocultural linguistics. }\end{array}$ \\
\hline $\begin{array}{r}\text { Week } \\
11\end{array}$ & 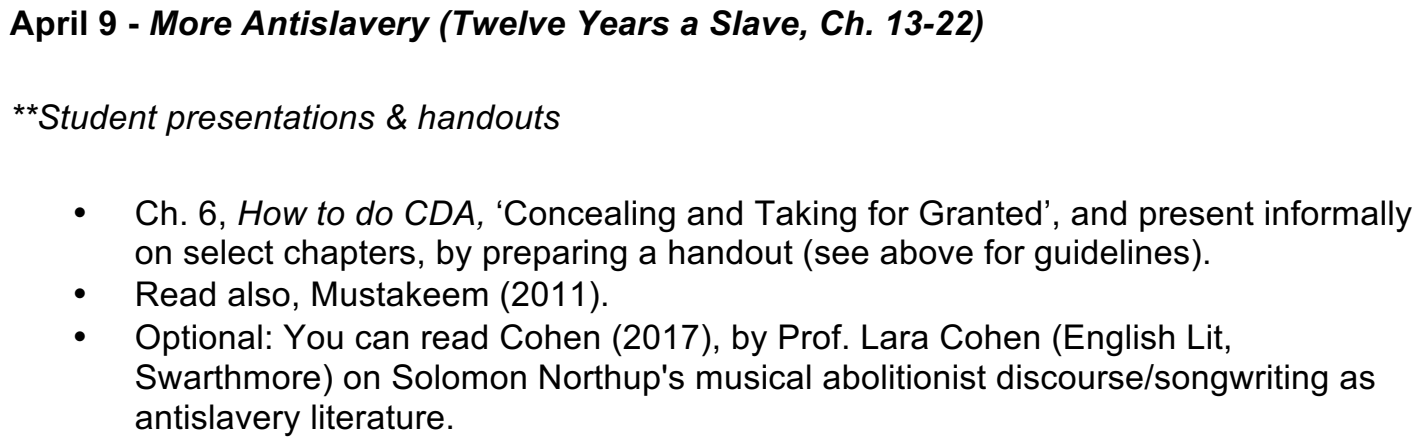 \\
\hline $\begin{array}{r}\text { Week } \\
12\end{array}$ & 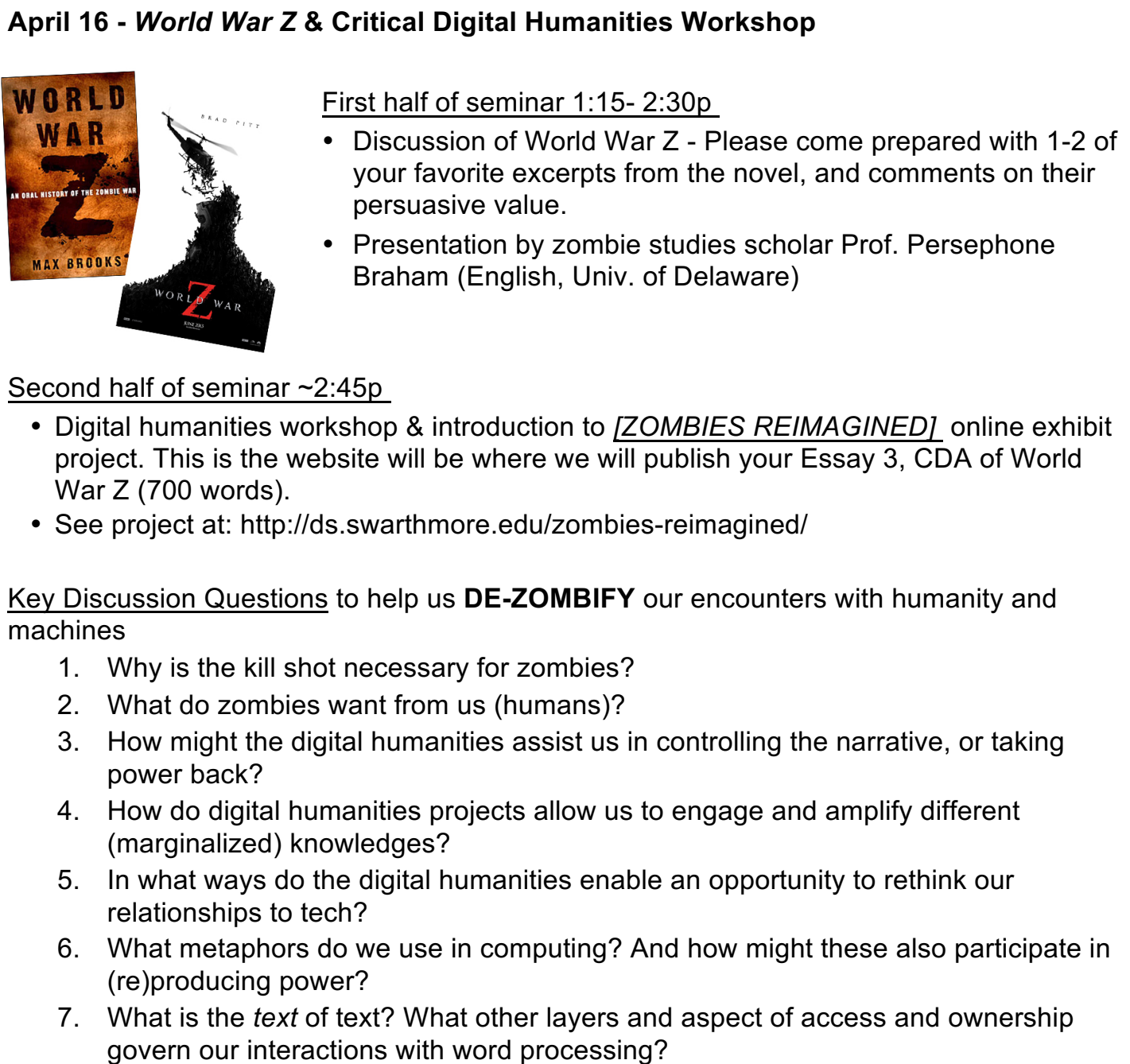 \\
\hline
\end{tabular}




\begin{tabular}{|r|l|}
$\begin{array}{r}\text { Week } \\
13\end{array}$ & April 23 - Review of Key Concepts \\
\hline $\begin{array}{r}\text { Week } \\
14\end{array}$ & April 30 - [ZOMBIES REIMAGINED] Project Day + Short Story Workshop \\
& $\begin{array}{l}\text { **Essay } 3 \text { due today for in-class peer review } \\
\text { We'll use this final day of class to workshop your final essays and short stories, and post } \\
\text { these to Prose.io (via your Github account) and the [ZOMBIES REIMAGINED] online } \\
\text { exhibit. }\end{array}$ \\
\hline & Final short stories due - May 11 via email \\
\hline
\end{tabular}

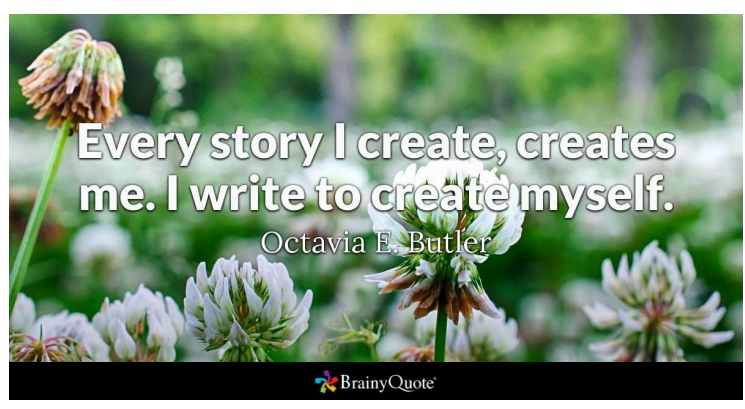

